\title{
Analisis Abnormal Return Saham pada Peristiwa Merger dan Akuisisi di Indonesia
}

\author{
Laurenza Sandra R. Ayu Putri ${ }^{1}$, Ima Kristina Yulita ${ }^{2}$, dan Aurelia M. Nisita Wardhani ${ }^{3}$ \\ ${ }^{1}$ Bank Panin Cabang Mangga Dua Jakarta, Indonesia \\ ${ }^{2}$ Jurusan Manajemen, Fakultas Ekonomi, Universitas Sanata Dharma, Yogyakarta, Indonesia \\ ${ }^{3}$ Jurusan Akuntansi, Fakultas Ekonomi, Universitas Sanata Dharma, Yogyakarta, Indonesia \\ $\underline{\text { laurensasandrarsta13@gmail.com }}^{1}$, yulitaimakristina@gmail.com ${ }^{2}, \underline{\text { nisita.wardhani@usd.ac.id }}^{3}$
}

DOI: https://doi.org/10.24071/exero.v3i2.4300

\begin{abstract}
Abstrak
Penelitian ini bertujuan untuk memperoleh bukti empiris terkait reaksi pasar yang diindikasikan dengan abnormal return pada seputaran waktu pengumuman merger dan akuisisi periode tahun 2016-2019. Populasi dalam penelitian adalah seluruh perusahaan yang terdaftar di Bursa Efek Indonesia yang sudah melakukan merger dan akuisisi. Teknik pengambilan sampel menggunakan purposive sampling, data yang diperoleh 12 perusahaan yaitu 3 perusahaan melakukan merger dan 9 perusahaan melakukan akuisisi. Teknik analisis data dalam penelitian ini adalah uji metode one sample kolmogorov-smirnov test, uji paired sample t-test, dan one sample t-test menggunakan aplikasi SPSS versi 25. Hasil penelitian menunjukkan bahwa: selama periode pengamatan 11 hari terdapat average abnormal return negatif yang tidak signifikan selama 7 hari dan average abnormal return positif yang tidak signifikan selama 4 hari pada seputaran waktu pengumuman merger dan akuisisi perusahaan. Hasil pengujian yang tidak signifikan ini membuktikan bahwa pasar tidak bereaksi selama periode pengamatan sebelum dan sesudah merger dan akuisisi.
\end{abstract}

Kata kunci: merger, akuisisi, abnormal return

\begin{abstract}
This study aims to obtain empirical evidence related to market reactions indicated by abnormal returns around the time of the 2016-2019 merger and acquisition announcement. The population in this study are companies listed on the Indonesia Stock Exchange that have conducted mergers and acquisitions. The sampling technique uses purposive sampling, the data obtained by 12 companies, namely 3 companies do mergers and 9 companies make acquisitions. Data analysis techniques in this study were one sample test method Kolmogorv-Smirnov test, paired sample t-test test, and one sample t-test using SPSS application version 25. The results of this study showed: During the 11 days study period, there were average abnormal return negative that insignificant for 7 days and average abnormal return positive that also insignificant for 4 days around the announcement time of the company's mergers and acquisitions. These insignificant test results prove that the market was not approved during the period before and after mergers and acquisitions.
\end{abstract}

Keywords: mergers, acquisitions, abnormal returns

\section{Pendahuluan}

Perubahan lingkungan bisnis yang didukung oleh kemajuan teknologi informasi yang sangat pesat serta adanya era perdagangan pasar bebas membuat perusahaan bersaing dengan ketat dan tajam. Ini dikarenakan masuknya era pasar bebas yang menuntut perusahaan untuk dapat berkompetisi dengan baik dan lebih 
kreatif agar tetap dapat bertahan dalam dunia usaha. Kondisi persaingan yang ketat dan tajam mendorong perusahaan untuk mengembangkan strategi perusahaan agar dapat bertahan bahkan berkembang. Perusahaan perlu mengembangkan suatu strategi yang tepat agar bisa mempertahankan eksistensinya dan memperbaiki kinerjanya. Strategi tersebut yaitu melalui penggabungan usaha antara dua perusahaan atau lebih yang disebut merger dan akuisisi.

Menurut Undang-undang Perseroan Terbatas Nomor 40 (UUPT) tahun 2007 pasal 1 ayat 9 dalam Setiawan dan Rasmini (2018), merger merupakan perbuatan hukum yang dilakukan oleh satu perseroan atau lebih untuk menggabungkan diri dengan perseroan lain yang telah ada yang mengakibatkan aktiva dan pasiva dari perseroan yang menggabungkan diri beralih karena hukum kepada perseroan yang menerima penggabungan dan selanjutnya status badan hukum perseroan yang menggabungkan diri berakhir karena hukum. Pasal UUPT Nomor 40 tahun 200711 ayat 11 menjelaskan bahwa akuisisi merupakan perbuatan hukum yang dilakukan oleh badan hukum atau orang perseorangan untuk mengambil alih saham perseroan yang mengakibatkan beralihnya pengendalian atas perseroan tersebut (Setiawan dan Rasmini, 2018).

Perusahaan cenderung memilih merger dan akuisisi daripada pertumbuhan internal sebagai strateginya karena merger dan akuisisi dianggap jalan cepat untuk mewujudkan tujuan perusahaan agar tidak perlu memulai dari awal suatu bisnis baru (Nugroho, 2010). Alasan lainnya adalah untuk meningkatkan pertumbuhan perusahaan. Perusahaan yang menginginkan pertumbuhan yang cepat, baik ukuran pasar saham maupun diversifikasi usaha dapat melakukan penggabungan usaha melalui merger ataupun akuisisi. Adanya penggabungan usaha membantu perusahaan memperkecil resiko adanya produk baru, sebab membeli lini produk dan pasar yang telah didirikan biasanya memiliki resiko yang lebih kecil dibandingkan dengan mengembangkan produk baru dan pasarnya. Selain itu, dengan melakukan penggabungan usaha maka perusahaan dapat mengurangi perusahaan pesaing atau mengurangi persaingan.

Menurut Tandelilin (2010:571), ketepatan respon pasar berkaitan dengan adanya reaksi pasar yang benar. Hal ini diindikasikan oleh arah respon pasar bersifat positif atau negatif. Indikator tersebut tampak dari return tak normal (abnormal 
return). Abnormal return merupakan selisih (positif atau negatif) dari return aktual dengan expected return. Adanya abnormal return menunjukkan adanya respon pasar terhadap informasi berupa merger dan akuisisi. Respon pasar dapat berupa respon positif (apabila informasi dianggap kabar baik) dan sebaliknya, respon pasar dapat berupa respon negatif (apabila informasi dianggap kabar buruk).

Namun merger dan akuisisi masih sering dipandang sebagai keputusan kontroversial karena memiliki dampak yang sangat dramatis dan kompleks. Banyak pihak yang dirugikan, sekaligus diuntungkan dari peristiwa merger dan akuisisi. Dampak yang merugikan dapat kita lihat dari sisi karyawan karena kebijakan ini sering disertai dengan pemutusan hubungan kerja (PHK) yang jumlahnya tidak sedikit. Perubahan-perubahan yang terjadi setelah perusahaan melakukan merger dan akuisisi biasanya akan tampak pada kinerja perusahaan dan penampilan finansialnya. Pasca merger, kondisi dan posisi keuangan perusahaan mengalami perubahan dan hal ini tercermin dalam laporan keuangan perusahaan yang melakukan merger. Perusahaan yang melakukan akuisisi biasanya didasari oleh motivasi mencapai sinergi. Manfaat ekstra atau sinergi ini tidak bisa diperoleh seandainya perusahaanperusahaan tersebut bekerja secara terpisah, dan untuk ekspansi bisnis nantinya diharapkan akan mampu menaikan nilai perusahaan terutama bagi perusahaan yang listed di Bursa Efek Indonesia (BEI).

Pengumuman merger dan akuisisi adalah informasi yang sangat penting dalam suatu industri karena dua perusahaan akan menyatukan kekuatannya. Konsekuensinya, peta persaingan dalam suatu industri akan berubah. Dengan demikian, pengumuman merger dan akuisisi merupakan suatu informasi yang dapat berpengaruh tidak hanya pada kedua perusahaan yang melakukan merger/akuisisi, namun juga perusahaan lain yang berada dalam industri yang sama. Tandelilin (2010) berpendapat bahwa dalam pasar efisien, harga sekuritas seharusnya merefleksikan informasi mengenai risiko dan harapan mengenai return masa datang.

Pengujian kandungan informasi dimaksudkan untuk melihat reaksi dari suatu pengumuman. Apabila pengumuman tersebut mengandung informasi maka pasar diharapkan akan bereaksi pada waktu informasi tersebut diterima oleh pasar. Jika pasar bereaksi dengan cepat dan akurat untuk mencapai harga keseimbangan baru 
yang sepenuhnya mencerminkan informasi yang tersedia, maka kondisi pasar disebut dengan pasar efisien (Hartono, 2017:605).

Abnormal return umumnya terjadi karena dipicu oleh beberapa peristiwa seperti penggabungan perusahaan, pengumuman dividen, meningkat dan menurunnya suku bunga, tuntutan hukum yang sesuai dengan kebijakan yang berlaku. Dalam hal ini, informasi pasar dapat digambarkan melalui Indeks Harga Saham Gabungan (IHSG). Jika IHSG mengalami kenaikan berarti reaksi pasar positif sehingga secara tidak langsung terjadi peningkatan kemakmuran pemegang saham, apabila IHSG mengalami penurunan maka dapat dikatakan pasar bereaksi negatif atau terjadi penurunan kemakmuran pemegang saham.

Beberapa penelitian telah dilakukan untuk menginvestigasi pengaruh merger dan akuisisi terhadap abnormal return saham \& pengaruh pengumuman merger dan akuisisi terhadap return saham, namun hasilnya tidak selalu konsisten. Penelitian oleh Rusnanda dan Pardi (2013) menganalisa pengaruh pengumuman merger dan akuisisi terhadap abnormal return saham bank umum di Bursa Efek Indonesia pada tahun 2006-2010. Hasil penelitian menunjukkan bahwa tidak ada perbedaan rata-rata abnormal return yang signifikan sebelum dan sesudah peristiwa akuisisi. Sihombing dan Kamal (2016) meneliti tentang pengaruh merger dan akuisisi terhadap abnormal return saham dan kinerja keuangan pada perusahaan yang terdaftar di Bursa Efek Indonesia yang melakukan dan mengumumkan merger dan akuisisi pada periode tahun 2011. Hasil penelitian ini menunjukkan bahwa merger dan akuisisi tidak memberikan dampak secara ekonomis bagi perusahaan dalam pengukuran terhadap abnormal return. Pratama (2017) menguji perbedaan abnormal return dan volume perdagangan sebelum dan sesudah peristiwa merger dan akuisisi di pada perusahaan perbankan yang terdaftar di Bursa Efek Indonesia pada tahun 2005-2014. Hasil penelitian ini menunjukkan bahwa hanya abnormal return yang memiliki perbedaan signifikan sementara volume perdagangan tidak memiliki perbedaan yang signifikan. Hal ini menunjukkan bahwa peristiwa merger dan akuisisi mengandung informasi yang ditanggapi oleh investor sebagai sinyal negatif sehingga mempengaruhi pengembalian saham tetapi tidak mempengaruhi likuiditas saham.

Perubahan pada perusahaan melakukan aktivitas merger dan akuisisi antara lain dapat dilihat dari penampilan finansial dan adanya reaksi pasar yang dibuktikan 
dengan abnormal return saham yang mencerminkan kesejahteraan pemegang saham. Hal ini menarik untuk diteliti kembali yaitu apakah terdapat abnormal return di sekitar pengumuman M\&A yang terdaftar di BEI (Bursa Efek Indonesia) periode tahun 2016-2019. Oleh karena itu, rumusan masalah dalam penelitian ini adalah: "Apakah terdapat reaksi pasar yang dibuktikan dengan abnormal return saham pada seputaran waktu peristiwa merger dan akuisisi periode tahun 2016-2019?”

\section{Kajian Literatur}

\section{Abnormal Return Saham}

Menurut Hartono (2017:667), abnormal return merupakan kelebihan dari return yang sesungguhnya terjadi terhadap return normal. Return normal merupakan return ekspektasi (expected return) atau return yang diharapkan oleh investor. Dengan demikian, abnormal return adalah selisih antara return atau tingkat keuntungan yang sebenarnya (actual return) dengan tingkat keuntungan yang diharapkan (expected return). Abnormal return biasanya dijadikan sebagai dasar pengujian efisiensi pasar dan biasa terjadi sekitar pengumuman dalam sebuah peristiwa. Peristiwa yang dimaksud salah satunya mencakup merger dan akuisisi. Abnormal return ini muncul akibat adanya peningkatan aktivitas perdagangan yang signifikan. Selain itu, terdapat indikasi order imbalance yang memiliki potensi untuk menyebabkan pergerakan harga yang lebih kuat. Abnormal return ini dapat dianalisis dengan menggunakan metode Market Model.

Abnormal return saham perusahaan mempunyai 2 arah yaitu positif dan negatif. Abnormal return positif menunjukkan bahwa pemegang saham perusahaan memperoleh return saham diatas return pasar pada hari perdagangan tersebut. Sedangkan abnormal return negatif berarti return saham yang diperoleh lebih kecil dari return pasar. Pengujian abnormal return tidak dilakukan untuk tiap-tiap sekuritas, tetapi dilakukan secara agregat dengan menguji rata-rata abnormal return (average abnormal return) seluruh sekuritas secara cross-section untuk tiap-tiap di periode peristiwa. 


\section{Merger dan Akuisisi}

\section{Pengertian Merger dan Akuisisi}

Setiap pemilik perusahaan pasti menghendaki adanya suatu perkembangan dalam perusahaan yang telah didirikannya. Agar tingkat perkembangkan perusahaan tersebut dapat sesuai dengan yang diharapkan maka diperlukan suatu perencanaan yang matang. Penggabungan usaha dalam bentuk merger dan akuisisi merupakan salah satu perencanaan yang dipilih.

Menurut Tarigan (2016:7), merger dapat didefinisikan sebagai sebuah gabungan antara dua organisasi atau lebih, dan hanya ada satu perusahaan yang bertahan. Setelah terjadi pengambilan tersebut maka perseroan yang diambil alih dibubarkan atau dilikuidasi sehingga eksistensinya sebagai badan hukum lenyap. Dengan demikian, kegiatan usahanya dilanjutkan oleh perseroan yang mengambil alih. Perusahaan yang dipertahankan akan membeli sebagian besar saham perusahaan yang dihapuskan tersebut, paling sedikit 50\% dari total saham yang dimiliki sehingga tidak ada lagi hak untuk menjalankan kegiatan bisnis. Menurut Moin (2010:5), merger adalah proses untuk menggabungkan dua perusahaan atau lebih dimana hanya ada satu perusahaan yang tetap berdiri sebagai badan hukum, sedangkan yang lainnya dibubarkan dan seluruh aset dan kewajiban yang dimiliki oleh perusahaan yang dibubarkan tersebut akan beralih ke perusahaan yang tetap berdiri.

Moin (2010), mengemukakan bahwa akuisisi adalah bentuk pengendalian kepemilikan perusahaan oleh pihak pengakuisisi sehingga akan mengakibatkan berpindahnya kendali atas perusahaan yang diambil alih tersebut. Biasanya pihak pengakuisisi memiliki ukuran yang lebih besar dibandingkan dengan pihak yang diakuisisi. Secara umum, akuisisi adalah situasi dimana satu perusahaan membeli sebagian besar atau seluruh saham perusahaan lain untuk mengambil kendali. Sedangkan menurut Tarigan (2016:8), akuisisi merupakan salah satu jenis merger, salah satu perusahaan tetap ada tetapi kepemilikannya telah beralih kepada perusahaan yang mengakuisisi.

\section{Klasifikasi Merger dan Akuisisi}

Menurut Mardiyanto (2009:319), ada tiga jenis tipe merger yaitu:

1. Merger horizontal 
Merger horisontal merupakan merger antara perusahaan yang sama lini bisnisnya. Misalnya, merger antara sesama pabrikan peralatan mesin.

2. Merger vertical

Merger vertikal merupakan perusahaan yang mempunyai hubungan pemasokpelanggan. Misalnya, merger antara pabrikan peralatan-mesin dan pemasok cetakan peralatan.

3. Merger kongenerik

Merger kongenerik merupakan merger yang diberikan kepada investor saat ini untuk membeli saham baru yang dikeluarkan emiten dalam rangka menghimpun dana segar.

Haryani (2011:25-28) menyatakan bahwa akuisisi dibedakan menjadi beberapa jenis menurut jenis usaha yaitu:

1. Akuisisi horizontal

Akuisisi horizontal merupakan akuisisi yang dilakukan oleh suatu badan usaha yang masih berkecimpung dalam bidang bisnis yang sama.

2. Akuisisi vertikal

Akuisisi vertikal merupakan akuisisi yang dilakukan oleh suatu badan usaha yang bergerak di bidang industri hilir dengan hulu atau sebaliknya.

3. Akuisisi konglomerat

Akuisisi konglomerat merupakan akuisisi badan usaha yang tidak memiliki bidang bisnis yang sama atau tidak saling berkaitan.

Menurut Haryani (2011:25-28), pengelompokan akuisisi dari obyek yang diakuisisi atau bentuk dasar yaitu:

1. Akuisisi aset

Akuisisi aset merupakan suatu aktivitas akuisisi suatu perusahaan yang memiliki tujuan untuk menghindari perusahaan dari kemungkinan memiliki pemilik saham yang kecil atau pemilik saham yang minoritas.

2. Akuisisi penggabungan

Akuisisi penggabungan biasa disebut sebagai akuisisi konsolidasi atau akuisisi merger ini merupakan akuisisi yang dilakukan untuk 
menyatukan dua atau lebih perusahaan agar bergabung menjadi suatu perusahaan baru.

3. Akuisisi saham

Akuisisi saham merupakan pembelian saham dari suatu perusahaan yang akan diakuisisi, bentuk akuisisi saham beragam bisa berupa secara tunai ataupun bentuk lain.

\section{Alasan melakukan Merger dan Akuisisi}

Menurut Tarigan (2016:33), merger dan akuisisi dapat dibedakan berdasarkan motif, yaitu:

1. Shareholder gains

Motif ini bertujuan untuk meningkatkan nilai perusahaan yang melakukan merger, karena merger meningkatkan profit aktual atau profit di masa depan dan demikian pihak yang mencari keuntungan melalui merger adalah pemegang saham.

\section{Managerial Gains}

Managerial gains merupakan motif untuk kepentingan manajer perusahaan dan tidak selalu untuk kepentingan perusahaan. Dengan kata lain, tujuan dari merger adalah semata-mata untuk keuntungan manajemen perusahaan bukan pemilik.

\section{Kelebihan dan Kekurangan Merger dan Akuisisi}

Menurut Moin (2010:13), alasan perusahaan melakukan merger dan akuisisi adalah adanya manfaat lebih penting yang diperoleh dari aktivitas tersebut. Secara spesifik, keunggulan dan manfaat merger dan akuisisi antara lain adalah:

1. Mendapatkan cash flow dengan cepat karena produk dan pasar sudah jelas.

2. Memperoleh kemudahan dana/pembiayaan karena kreditor lebih percaya dengan perusahaan yang telah berdiri dan mapan.

3. Memperoleh karyawan yang telah berpengalaman.

4. Mendapatkan pelanggan yang telah mapan tanpa harus merintis dari awal.

5. Mengurangi resiko kegagalan bisnis karena tidak harus mencari konsumen baru.

6. Menghemat waktu untuk memasuki bisnis baru

Menurut Moin (2010:13), kelemahan melakukan merger dan akuisisi, yaitu: 
1. Kesulitan menentukan nilai perusahaan target secara akurat

2. Biaya konsultan yang mahal

3. Tidak menjamin peningkatan nilai perusahaan

4. Tidak menjamin peningkatan kemakmuran pemegang saham

\section{Event Study}

Studi tentang suatu peristiwa (event study) sering dilakukan oleh para peneliti di bidang keuangan, terutama yang meneliti tentang keuangan pasar modal. Peristiwa yang dimaksud ini adalah peristiwa yang terjadi dalam kebijakan internal perusahaan, salah satunya yaitu kebijakan untuk melakukan merger dan akuisisi. Menurut Tandelilin (2010:239), penelitian event study umumnya berkaitan dengan seberapa cepat suatu informasi yang masuk ke pasar dapat tercermin pada harga saham. Bentuk peristiwa yang diinformasikan beragam baik informasi dari perusahaan maupun luar perusahaan yang mungkin akan mempengaruhi prospek pertumbuhan di masa datang.

Event study ini melakukan penilaian dampak kejadian yang merupakan syarat untuk mengukur abnormal return. Informasi yang dipublikasikan ini merupakan informasi dalam pengumuman oleh perusahaan emiten. Informasi ini umumnya berhubungan dengan peristiwa yang terjadi di perusahaan emiten.

\section{Teori Efisiensi Pasar}

Menurut Tandelilin (2010:219), pasar yang efisien jika harga semua sekuritas yang diperdagangkan telah mencerminkan semua informasi yang tersedia. Dalam hal ini, informasi yang tersedia bisa meliputi semua informasi yang tersedia baik informasi di masa lalu (misalkan laba perusahaan tahun lalu), maupun informasi saat ini (misalkan rencana kenaikan dividen tahun ini), serta informasi yang bersifat sebagai pendapat/opini rasional yang beredar di pasar yang bisa mempengaruhi perubahan harga (misal, jika banyak investor di pasar berpendapat bahwa harga saham akan naik, maka akan informasi tersebut nantinya tercermin pada perubahan harga saham yang cenderung naik).

Pasar modal efisien terbagi menjadi tiga tingkat menurut Tandelilin (2010:223) yaitu: 
1. Pasar efisien bentuk lemah (weak form) berarti semua informasi di masa lalu (historis) akan tercermin dalam harga yang terbentuk sekarang. Oleh karena itu, informasi historis (seperti harga dan volume perdagangan) tidak bisa lagi digunakan untuk memprediksi perubahan harga di masa yang datang, karena sudah tercermin pada harga saat ini.

2. Pasar efisien bentuk setengah kuat (semi strong) berati harga pasar saham yang terbentuk sekarang telah mencerminkan informasi historis ditambah dengan semua informasi yang dipublikasikan (seperti earning, dividen, dan penerbitan saham baru). Suatu pasar dinyatakan efisien dalam bentuk setengah kuat bila informasi terserap atau direspon dengan cepat oleh pasar.

3. Pasar efisien bentuk kuat (strong form) berati harga pasar saham yang terbentuk sekarang telah mencerminkan informasi historis ditambah dan semua informasi yang dipublikasikan ditambah dengan informasi yang tidak dipublikasikan. Pada pasar efisien bentuk kuat tidak ada ada seorang investor pun yang bisa memperoleh return tak normal.

Ketiga bentuk pasar efisien ini saling berhubungan satu dengan yang lainnya. Hubungan ketiga bentuk pasar efisien ini berupa tingkatan yang kumulatif, yaitu bentuk lemah merupakan bentuk dari setengah kuat dan bentuk setengah kuat merupakan bagian dari bentuk kuat. Untuk kondisi efisiensi pasar di Indonesia dengan kondisi yang tidak menentu belum dapat dikategorikan kedalam bentuk efisiensi pasar yang lemah, semi kuat, maupun bentuk kuat. Hal ini tergantung dari seberapa cepat pasar bereaksi terhadap informasi yang didapat.

Menurut Hartono (2017), bahwa untuk jenis pasar semi kuat dapat dilihat dari seberapa cepat pasar bereaksi terhadap informasi yang dipublikasikan. Untuk itu, dalam penelitian ini jenis pasar yang dapat disimpulkan yaitu jenis pasar semi kuat yaitu dilihat dari kecepatan reaksinya sehingga menghasilkan abnormal return bagi perusahaan.

\section{Signaling Theory}

Menurut Brigham dan Houston (2014:184), signaling theory merupakan suatu perilaku manajemen perusahaan dalam memberi petunjuk untuk investor terkait pandangan manajemen pada prospek perusahaan untuk masa mendatang. 
Dorongan perusahaan untuk memberikan informasi karena terdapat asimetri informasi antara perusahaan dan pihak luar karena perusahaan mengetahui lebih banyak mengenai perusahaan dan prospek yang akan datang daripada pihak luar (investor dan kreditor). Informasi tersebut bisa berupa laporan keuangan, informasi kebijakan perusahaan maupun informasi lain yang diungkapkan secara sukarela oleh manajemen perusahaan. Brigham dan Houston (2014) juga menyatakan bahwa teori sinyal adalah suatu tindakan yang diambil oleh manajemen perusahaan yang memberikan petunjuk bagi investor tentang bagaimana manajemen memandang prospek perusahaan. Perusahaan ini mengadopsi sinyal-sinyal ini untuk mengungkapkan atribut yang tersembunyi untuk para yang berkepentingan.

\section{Perumusan Hipotesis}

\section{Pengaruh Merger dan Akuisisi terhadap Abnormal Return}

Merger dan akuisisi merupakan salah satu strategi dapat dilakukan perusahaan untuk mempercepat pertumbuhan perusahaan sedangkan pengumuman merger dan akuisisi dapat mengakibatkan timbulnya reaksi pada pasar saham. Reaksi pada pasar saham ini dapat dilihat dari perubahan harga saham yang akhirnya dapat mengindikasikan besarnya jumlah abnormal return diterima oleh para pemegang saham. Naiknya permintaan saham akan berpengaruh pada naiknya harga saham perusahaan di pasar modal. Dengan demikian nilai perusahaan semakin meningkat yang pada akhirnya kinerja perusahaan juga akan meningkat.

Pada dasarnya tindakan merger dilakukan oleh perusahaan untuk menuju arah yang lebih baik. Merger merupakan suatu tindakan agar perusahaan yang melakukannya dapat menciptakan nilai perusahaan yang lebih baik atau dengan kata lain akan terdapat peningkatan kinerja perusahaan, khususnya financial performance perusahaan setelah melakukan merger dan akuisisi. Perubahan harga saham kedua perusahaan tersebut mengindikasikan besarnya tingkat kemakmuran yang diperoleh pemegang saham sebagai dampak dari pengumuman merger dan akuisisi. Dalam penelitian ini, tingkat kemakmuran pemegang saham diukur dari besarnya abnormal return yang diperoleh pemegang saham perusahaan yang melakukan merger dan akuisisi. Pratama (2017) meneliti mengenai analisis reaksi pasar sebelum dan sesudah peristiwa merger dan akuisisi pada tahun 2005-2014. Hasil penelitian ini 
menunjukkan bahwa hanya abnormal return yang memiliki perbedaan signifikan. Hipotesis yang diajukan dalam penelitian ini adalah :

Ha: Terdapat dampak pengumuman merger dan akuisisi yang menghasilkan abnormal return signifikan pada periode di sekitar tanggal pengumuman.

\section{Metode Penelitian}

\section{Jenis penelitian}

Penelitian ini merupakan studi peristiwa (event study) yaitu studi yang mempelajari reaksi pasar terhadap suatu peristiwa (event) yang informasinya dipublikasikan sebagai suatu pengumuman. Menurut Tandelilin (2010:239), penelitian event study umumnya berkaitan dengan seberapa cepat suatu informasi yang masuk ke pasar dapat tercermin pada harga saham. Bentuk peristiwa yang diinformasikan beragam baik informasi dari perusahaan maupun luar perusahaan yang mungkin akan mempengaruhi prospek pertumbuhan di masa datang. Jika pengumuman mengandung informasi maka pasar diharapkan akan bereaksi pada waktu pengumuman tersebut diterima oleh pasar. Sementara itu, menurut Hartono (2017:643), event study dapat digunakan untuk menguji hipotesis pasar efisien pada bentuk setengah kuat (semi-strong form). Peristiwa yang dimaksud dalam penelitian ini adalah peristiwa pengumuman merger dan akuisisi yang dilakukan perusahaan yang terdaftar di BEI.

\section{Variabel dan Pengukuran Variabel}

Di sisi lain, penelitian ini menggunakan variabel yang diamati adalah perilaku harga tingkat keuntungan tidak normal (abnormal return). Hal ini digunakan untuk memperoleh gambaran yang jelas mengenai dampak atau pengaruh pengumuman sebelum dan sesudah merger dan akuisisi terhadap pasar. Dengan demikian, penelitian ini menggunakan metode event study dan menggunakan variabel yang diamati yaitu abnormal return.

Selanjutnya, variabel independen yang digunakan dalam penelitian ini yaitu peristiwa merger dan akuisisi. Menurut Sugiyono (2017:39), variabel independen adalah variabel yang mempengaruhi atau yang menjadi sebab perubahan atau timbulnya variabel dependen (terikat). Sementara itu, untuk variabel dependen 
merupakan jenis variabel yang telah dipengaruhi atau yang menjadi akibat karena adanya variabel bebas (Sugiyono, 2017:39). Variabel dependen dalam penelitian ini adalah abnormal return.

Studi peristiwa menganalisis return tak normal (abnormal return) dari sekuritas yang mungkin terjadi disekitar pengumuman dari suatu peristiwa. Return tak normal (abnormal return) adalah selisih antara return sesungguhnya yang terjadi dengan return ekspetasian, sebagai berikut:

$$
\text { ARit }=\text { Rit }-E(R i t)
$$

Keterangan:

ARit $=$ abnormal return saham i pada hari ke $\mathrm{t}$

Rit $=$ return sesungguhnya (actual return) saham i pada hari ke $\mathrm{t}$

$E($ Rit $)=$ return ekspetaksi (expected return) pada hari ke $\mathrm{t}$

Actual return saham diperoleh dengan mencari selisih antara harga saham penutupan harian dikurangi harga saham hari sebelumnya kemudian dibagi dengan harga saham hari sebelumnya. Adapun rumus untuk menghitung actual return adalah :

$$
R_{i t}=\frac{P_{i t}-P_{i t-1}}{P_{i+-1}}
$$

Keterangan:

$R_{i t}=$ return saham i pada hari ke $\mathrm{t}$

$P_{i t}=$ harga saham i pada hari ke $\mathrm{t}$

$P_{i t-1}=$ harga saham i pada hari ke $\mathrm{t}-1$

Pengujian adanya abnormal return tidak dilakukan untuk tiap-tiap sekuritas, tetapi dilakukan secara agregat dengan menguji rata-rata return tak normal seluruh sekuritas secara cross-section untuk tiap-tiap hari di periode peristiwa. Rata-rata return tak normal untuk hari ke-t dapat dihitung berdasarkan rata-rata aritmatika sebagai berikut

Keterangan:

$$
A A R_{t}=\frac{\sum_{i=1}^{k} A R_{i t}}{k}
$$

$A A R t=$ Average Abnormal Return pada hari ke $\mathrm{t}$

ARit = Abnormal Return untuk sekuritas i pada hari ke $\mathrm{t}$

$\mathrm{k}=$ jumlah sekuritas yang terpengaruh oleh pengumuman peristiwa 
Selanjutnya tingkat keuntungan yang diharapkan (expected return) dihitung dengan menggunakan Market Adjusted Model. Dalam model ini, expected return merupakan return saham yang diukur dengan menggunakan indeks harga saham gabungan (IHSG) dengan rumus sebagai berikut:

$$
\mathrm{E}\left(\mathrm{R}_{\mathrm{it}}\right)=\frac{\mathrm{IHSG}_{\mathrm{t}}-\mathrm{IHSG}_{\mathrm{t}-1}}{\mathrm{IHSG}_{\mathrm{t}-1}}
$$

Keterangan:

$E\left(R_{i t}\right)=$ return ekspektasi pada hari ke $\mathrm{t}$

$I H S G_{t}=$ indeks harga saham gabungan pada hari ke $\mathrm{t}$

$I H S G_{\mathrm{t}-1}=$ indeks harga saham gabungan pada hari ke $\mathrm{t}-1$

\section{Populasi dan Sampel}

Penelitian ini menggunakan seluruh perusahaan yang terdaftar di Bursa Efek Indonesia yang sudah melakukan merger dan akuisisi sebagai populasi. Sampel dipilih dengan menggunakan metode purposive sampling, yaitu memiliki kriteria tertentu agar sampel yang diperoleh pada penelitian ini representatif. Adapun kriteria yang digunakan dalam penelitian ini sebagai berikut:

1. Perusahaan masih terdaftar di Bursa Efek Indonesia selama periode penelitian yaitu tahun 2016 sampai dengan tahun 2019.

2. Perusahaan melakukan aktivitas merger dan akuisisi pada periode tahun 2016 sampai dengan 2019.

3. Tanggal dilakukan merger dan akuisisi jelas.

4. Ada berita pengumuman merger dan akuisisi di Bursa Efek Indonesia.

5. Perusahaan memiliki harga saham yang jelas pada periode tahun 2016 sampai dengan 2019.

Berdasarkan lima kriteria tersebut terdapat sebanyak 24 perusahaan yang melakukan merger dan akuisisi yaitu 4 perusahaan melakukan merger dan 20 perusahaan melakukan akuisisi pada periode tahun 2016-2019. Namun, berdasarkan kriteria yang telah ditentukan hanya terdapat 12 perusahaan yang memenuhi kriteria. Data mengenai 12 perusahaan yang menjadi sampel penelitian beserta tanggal merger dan akuisisi dapat dilihat pada tabel 2. Proses pemilihan sampel penelitian dapat dilihat secara rinci pada tabel 1 berikut ini: 
Tabel 1. Proses Pemilihan Sampel

\begin{tabular}{lc}
\hline \multicolumn{1}{c}{ Keterangan } & Jumlah \\
\hline Perusahaan yang melakukan merger dan akuisisi pada & 24 \\
periode 2016-2019 & \\
Perusahaan yang dikeluarkan dari sampel karena: & \\
1. Perusahaan bukan go publik di BEI \\
2. Perusahaan tidak memiliki harga saham pada periode \\
$\quad$ 2016-2019 \\
Total sampel perusahaan yang dipilih
\end{tabular}

\section{Data dan Sumber Data}

Di sisi lain, data yang digunakan dalam penelitian ini adalah data sekunder, yaitu data yang diperoleh dari pihak lain atau pihak luar yakni dari perusahaanperusahaan yang go public yang telah dipublikasi di Bursa Efek Indonesia. Data tersebut dikumpulkan dengan cara dokumentasi dari berbagai sumber, yaitu Indonesia Capital Market Directory (ICMD), yahoo finance, situs http://www.idx.co.id dan KPPU. Data sekunder dalam penelitian ini adalah:

1. Data perusahaan yang mengumumkan aktivitas merger dan akuisisi pada periode tahun 2016-2019

2. Data mengenai tanggal pengumuman merger dan akuisisi untuk masing-masing sampel perusahaan

3. Data harga saham harian dan Indeks Harga Saham Gabungan selama periode pengamatan 
Tabel 2

Sampel Perusahaan dan Tanggal Aktivitas Merger Dan Akuisisi Pada Periode 2016-2019

\begin{tabular}{|c|c|c|c|c|}
\hline$\overline{\text { No. }}$ & Kode & Perusahaan & Tanggal & Aktivitas \\
\hline 1. & DNAR & $\begin{array}{l}\text { PT Bank Oke Indonesia } \\
\text { Tbk }\end{array}$ & 06 Agustus 2019 & Merger \\
\hline 2. & BTPN & $\begin{array}{l}\text { PT Bank Tabungan } \\
\text { Pensiun }\end{array}$ & 21 Desember 2018 & Merger \\
\hline 3. & MCOR & $\begin{array}{l}\text { Nasional Tbk } \\
\text { PT Bank China } \\
\text { Construction }\end{array}$ & 17 Oktober 2016 & Merger \\
\hline 4. & SCMA & $\begin{array}{l}\text { Bank Indonesia Tbk } \\
\text { PT Surya Citra Media } \\
\text { Tbk }\end{array}$ & 09 Agustus 2019 & Akuisisi \\
\hline 5. & JAST & $\begin{array}{l}\text { PT Jasnita Telekomindo } \\
\text { Tbk }\end{array}$ & 01 Agustus 2019 & Akuisisi \\
\hline 6. & MEDC & $\begin{array}{l}\text { PT Medco Energi } \\
\text { Internasional Tbk }\end{array}$ & 22 Mei 2019 & Akuisisi \\
\hline 7. & SCMA & $\begin{array}{l}\text { PT Surya Citra Media } \\
\text { Tbk }\end{array}$ & 11 Maret 2019 & Akuisisi \\
\hline 8. & DSNG & $\begin{array}{l}\text { PT Dharma Satya } \\
\text { Nusantara Tbk }\end{array}$ & 12 Desember 2018 & Akuisisi \\
\hline 9. & ADRO & PT Adaro Energy Tbk & 01 Agustus 2018 & Akuisisi \\
\hline 10. & ZINC & $\begin{array}{l}\text { PT Kapuas Prima Coal } \\
\text { Tbk }\end{array}$ & 25 Juli 2018 & Akuisisi \\
\hline 11. & KARW & PT ICTSI Jasa Prima Tbk & 02 November 2017 & Akuisisi \\
\hline 12. & BRPT & PT Barito Pacific Tbk & 05 Desember 2016 & Akuisisi \\
\hline
\end{tabular}

Sumber: www.idx.co.id

\section{Teknik Analisis Data}

Teknik analisis data yang digunakan terdiri dari analisis deskriptif untuk menghitung rata-rata abnormal return dan One sample $t$ test untuk mengetahui ada tidaknya abnormal return yang signifikan di sekitar tanggal pengumuman merger dan akuisisi periode tahun 2016-2019. Di sisi lain, penelitian ini juga melakukan analisis data yaitu pengujian normalitas.

\section{Hasil dan Pembahasan}

\section{Analisis Data}

Untuk menjawab rumusan masalah apakah terdapat reaksi pasar yang dibuktikan dengan abnormal return saham pada seputaran waktu peristiwa merger dan akuisisi periode tahun 2016-2019, dilakukan langkah-langkah sebagai berikut: 
1. Menentukan periode pengamatan (periode jendela)

Pada penelitian ini periode pengamatan yang digunakan yaitu selama 11 hari. Abnormal return untuk periode pengamatan sebelum tanggal pengumuman peristiwa dihitung mulai hari $-5,-4,-3,-2,-1$. Abnormal return periode pengamatan setelah tanggal pengumuman peristiwa dihitung mulai hari +1 , $+2,+3,+4,+5$.

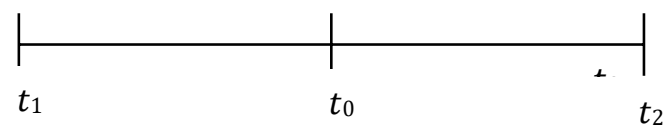

2. Menghitung return sesungguhnya (actual return) dengan rumus:

$$
R_{i t}=\frac{P_{i t}-P_{i t-1}}{P_{t-1}}
$$

Contoh perhitungan return sesungguhnya (actual return) DNAR pada $\mathrm{t}+1$ adalah sebagai berikut:

$$
\begin{gathered}
\mathrm{R}_{\text {DNAR }_{\mathrm{n}}+1}=\frac{260,00-270,00}{270,00} \\
\mathrm{R}_{\text {DNAR }+1_{1}}=-0.0370
\end{gathered}
$$

3. Menghitung besarnya return pasar selama periode peristiwa dengan rumus:

$$
\begin{aligned}
\mathrm{R}_{m t_{n}+1} & =\frac{6.240,20-6.119,47}{6.119,47} \\
\mathrm{R}_{m t+1} & =0,01384499
\end{aligned}
$$

4. Menghitung abnormal return selama periode peristiwa dengan rumus:

$$
A R_{i t}=R_{i t}-\mathrm{R}_{m t}
$$

Contoh perhitungan abnormal return DNAR untuk $t+1$ adalah sebagai berikut:

$$
\begin{gathered}
A R_{\text {DNAR + } 1}=(-0.0370)-0,01384499 \\
A R_{\text {DNAR +1 }}=-0,0509
\end{gathered}
$$

5. Menghitung rata-rata return tidak normal (average abnormal return) dengan rumus

$$
A A R_{n t}=\frac{\sum_{i=1}^{k} A R_{i t}}{n}
$$

Contoh perhitungan rata-rata return tidak normal (average abnormal return) pada periode $\mathrm{t}$ adalah sebagai berikut: 


$$
\begin{aligned}
& A A R_{n t}=\frac{\begin{array}{c}
(-0,0509)+0,0058+(-0,0222)+0,0289+0,0095+(-0,0064)+ \\
(-0,0323)+(-0,0191)+(-0,0021)+(-0,0014)+0,0603+(-0,0036)
\end{array}}{11} \\
& A A R_{n t}=-0,0088
\end{aligned}
$$

Gambar 1 menyajikan informasi dalam bentuk grafik yang menggambarkan rata-rata return tidak normal selama periode peristiwa. Pada gambar 1 dapat kita lihat bahwa rata-rata abnormal return yang bernilai positif terjadi pada hari t-3, t-2, t-1 dan $\mathrm{t}$. Sedangkan pada hari $\mathrm{t}-5, \mathrm{t}-4, \mathrm{t}+1, \mathrm{t}+2, \mathrm{t}+3, \mathrm{t}+4$ dan $\mathrm{t}+5$ terjadi abnormal return yang bernilai negatif. Rata-rata abnormal return yang bernilai positif menunjukkan bahwa perusahaan memperoleh return saham yang lebih tinggi dibandingkan return yang diharapkan. Sebaliknya bila rata-rata abnormal return yang bernilai negatif menunjukkan bahwa perusahaan memperoleh return saham yang lebih rendah dibandingkan return yang diharapkan.

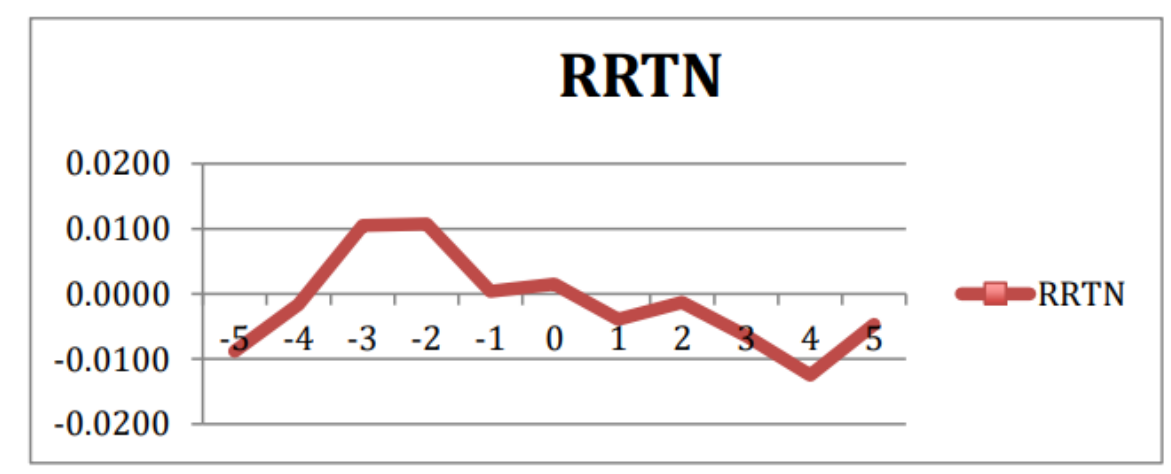

Gambar 1 Rata-rata Return Tidak Normal Selama Periode Pengamatan Sumber: data sekunder diolah, 2020

\section{Statistik Deskriptif}

Hasil perhitungan statistik deskriptif dari gambar 1 ini disajikan tabel 3 dalam yang menggambarkan statistik deskriptif selama periode peristiwa. Tabel 3 menunjukkan bahwa pengumuman merger dan akuisisi ternyata menghasilkan ratarata abnormal return yang negatif. Selama 11 hari periode pengamatan $\left(\square_{-5}\right.$ $\square \square \square \square \square \square \square+5$ ), diperoleh sebanyak 7 hari $(63,6 \%)$ rata-rata abnormal return negatif dan dihasilkan rata-rata abnormal return bernilai positif sebanyak 4 hari $(37,4 \%)$. Hasil ini menunjukkan bahwa secara umum keputusan perusahaan untuk 
melakukan kegiatan merger dan akuisisi direspon negatif oleh investor, dikarenakan harapan oleh pasar lebih tinggi daripada kenyataan.

Tabel 3

Statistik Deskriptif AAR Pada Event Window

\begin{tabular}{cccc}
\hline Periode & Minimum & Maximum & Mean \\
\hline H-5 & $-0,0716$ & 0,0441 & $-0,008069$ \\
H-4 & $-0,0278$ & 0,0609 & $-0,001508$ \\
H-3 & $-0,0498$ & 0,0553 & 0,009631 \\
H-2 & $-0,0217$ & 0,0571 & 0,009846 \\
H-1 & $-0,0733$ & 0,04 & 0,000362 \\
0 & $-0,035$ & 0,0412 & 0,001369 \\
H+1 & $-0,0509$ & 0,0603 & $-0,0036$ \\
H+2 & $-0,0334$ & 0,0348 & $-0,0012$ \\
H+3 & $-0,0368$ & 0,0277 & $-0,005908$ \\
H+4 & $-0,1431$ & 0,0468 & $-0,011446$ \\
H+5 & $-0,0497$ & 0,0384 & $-0,004315$ \\
\hline
\end{tabular}

Sumber: data diolah, 2020

\section{Hasil Uji Normalitas}

Untuk menentukan alat uji statistik yang tepat bagi hipotesis yang dibuat, maka terlebih dahulu dilakukan uji normalitas data dengan menggunakan One Sample Kolmogorov Smirnov Test pada probabilitas sebesar 5\%. Hasil perhitungan uji normalitas dapat dilihat pada tabel 4. Tabel tersebut menunjukkan bahwa nilai asymptotic significance adalah 0,200 yang lebih besar dari 0,05, baik pada pengujian terhadap AAR Sebelum dan AAR Sesudah. Atas dari dasar hasil pengujian ini, maka dapat disimpulkan bahwa data berdistribusi normal. Oleh karena data penelitian berdistribusi normal, maka uji beda yang akan digunakan ini adalah uji parametrik (paired sample t-test).

Sementara itu, hasil perhitungan uji beda dapat dilihat pada tabel 5. Tabel tersebut menunjukkan bahwa nilai t-hitung sebesar 1,520 dengan probabilitas (p) sebesar 0,203. Maka penelitian ini tidak dapat membuktikan secara empiris bahwa terdapat dampak abnormal return pada periode sebelum dan sesudah pengumuman merger dan akuisisi perusahaan, karena nilai probabilitas $(\mathrm{p})>\alpha=0,05$ yaitu sebesar 0,203. Atas dasar hasil penelitian ini, maka dapat disimpulkan bahwa tidak adanya reaksi pasar di seputar periode pengumuman merger dan akuisisi. Ini membuktikan bahwa para investor kurang tertarik untuk melakukan investasi di sepanjang periode dan tidak merespon peristiwa merger. Peristiwa ini dapat dikaitkan Signaling theory 
yang menyatakan bahwa ada peristiwa yang dapat memberikan sinyal terhadap reaksi informasi yang ada di pasar. Saat pengumuman telah dipublikasikan maka pelaku pasar menganalisis dan memilih informasi yang baik atau informasi yang buruk.

Tabel 4

Hasil Uji Normalitas Data One Sample Kolmogorov Smirnov Test One-Sample Kolmogorov-Smirnov Test

\begin{tabular}{|c|c|c|c|}
\hline & & $\begin{array}{l}\text { AAR } \\
\text { SEBELUM }\end{array}$ & $\begin{array}{c}A A R \\
\text { SESUDAH }\end{array}$ \\
\hline$N$ & & 5 & 5 \\
\hline \multirow{3}{*}{$\begin{array}{c}\text { Normal Parameters } \\
\text { Lanjutan }\end{array}$} & Mean & .002240 & -.005760 \\
\hline & Std. Deviation & .0083638 & .0041926 \\
\hline & Absolute & .238 & .239 \\
\hline \multirow[t]{2}{*}{ Most Extreme Differences } & Positive & .187 & .146 \\
\hline & Negative & -.238 & -.239 \\
\hline Test Statistic & & .238 & .239 \\
\hline $\begin{array}{l}\text { Asymp. Sig. (2-tailed) } \\
\text { a. Test distribution is Normal. } \\
\text { b. Calculated from data. }\end{array}$ & & .200 & .200 \\
\hline
\end{tabular}

Sumber: data sekunder diolah, 2020

Tabel 5

Hasil Uji Paired Samples Test AAR Periode Sebelum dan Sesudah Pengumuman Merger dan Akuisisi

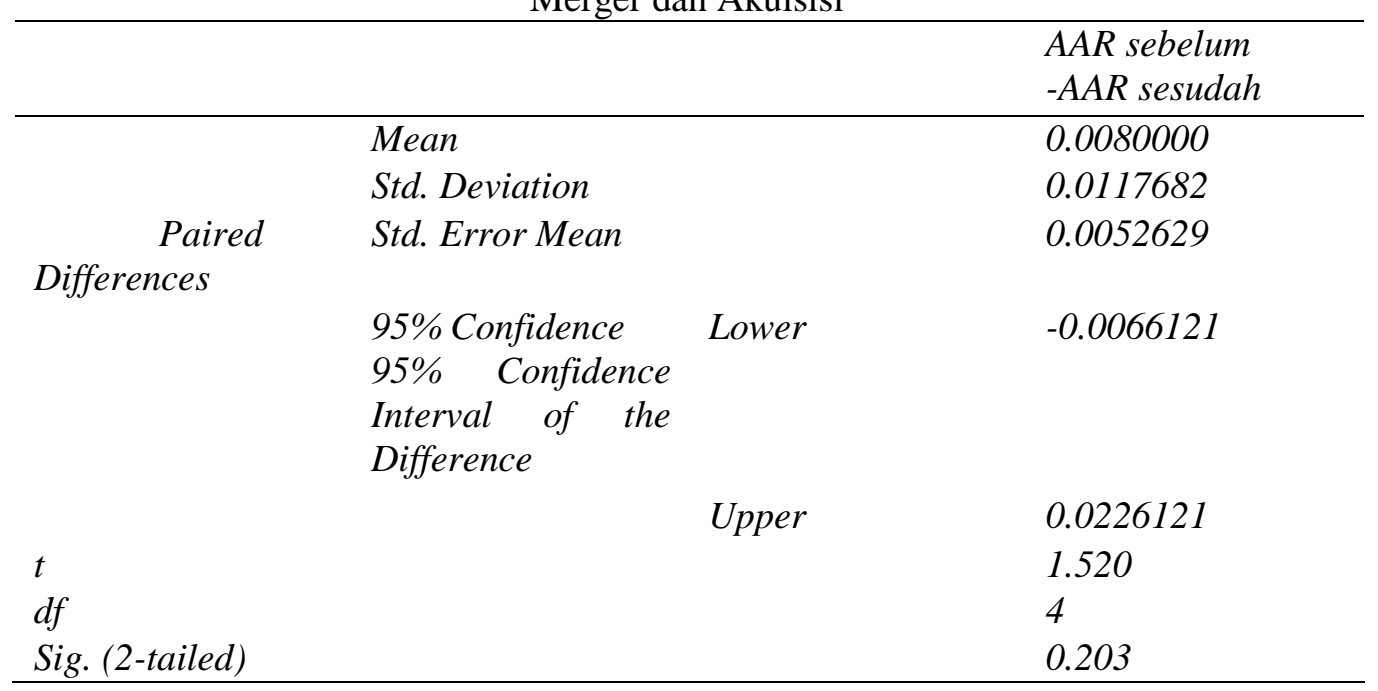

Sumber: data sekunder diolah, 2020

\section{Hasil Pengujian Hipotesis}

Pengujian hipotesis ini bertujuan untuk membuktikan apakah pengumuman merger dan akuisisi direspon oleh pasar, sehingga menghasilkan nilai AAR dengan nilai signifikan minimum $\square=5 \%$. Uji ini dilakukan dengan menggunakan teknik 
analisis One sample t-test. Hasil perhitungan dapat dilihat pada tabel 6 yang menggambarkan hasil uji t pada AAR selama event window.

Tabel 6 Hasil Uji-t Pada AAR Selama Event Window

\begin{tabular}{ccccc}
\hline Periode & AAR & t-hitung & $\begin{array}{c}\text { Probabilitas } \\
(\mathrm{P})\end{array}$ & Keterangan \\
\hline H-5 & $-0,0088$ & $-0,908$ & 0,382 & Tidak terdapat dampak \\
H-4 & $-0,0016$ & $-0,21$ & 0,837 & Tidak terdapat dampak \\
H-3 & 0,0105 & 1,227 & 0,243 & Tidak terdapat dampak \\
H-2 & 0,0107 & 1,636 & 0,128 & Tidak terdapat dampak \\
H-1 & 0,0004 & 0,048 & 0,962 & Tidak terdapat dampak \\
0 & 0,0015 & 0,255 & 0,803 & Tidak terdapat dampak \\
H+1 & $-0,0039$ & $-0,468$ & 0,648 & Tidak terdapat dampak \\
H+2 & $-0,0013$ & $-0,263$ & 0,797 & Tidak terdapat dampak \\
H+3 & $-0,0064$ & $-1,178$ & 0,261 & Tidak terdapat dampak \\
H+4 & -0.0125 & -0.876 & 0,398 & Tidak terdapat dampak \\
H+5 & $-0,0047$ & $-0,763$ & 0,46 & Tidak terdapat dampak \\
\hline
\end{tabular}

Sumber: data sekunder diolah, 2020

Tabel 6 mengindikasikan bahwa selama 11 hari periode pengamatan terdapat abnormal return yang tidak signifikan pada seputaran waktu pengumuman merger dan akuisisi perusahaan. Hasil pengujian data pada H-5, diperoleh nilai t sebesar 0,908 dengan signifikan sebesar 0,382. Nilai signifikansi lebih besar dari 0,05 $(0,382>0,05)$ sehingga tidak ada dampak pengumuman merger dan akuisisi yang menghasilkan abnormal return signifikan pada periode H-5. Selanjutnya, untuk hasil pengujian data pada $\mathrm{H}-4$, diperoleh nilai t sebesar $-0,21$ dengan signifikan sebesar 0,837. Nilai signifikansi lebih besar dari $0,05(0,837>0,05)$ sehingga tidak ada dampak pengumuman merger dan akuisisi yang menghasilkan abnormal return signifikan pada periode $\mathrm{H}-4$.

Kemudian, untuk hasil pengujian data pada H-3, diperoleh nilai t sebesar 1,227 dengan signifikan sebesar 0,243. Nilai signifikansi lebih besar dari 0,05 $(0,243>0,05)$ sehingga tidak ada dampak pengumuman merger dan akuisisi yang menghasilkan abnormal return signifikan pada periode H-3. Sementara itu, untuk hasil pengujian data pada $\mathrm{H}-2$, diperoleh nilai t sebesar 1,636 dengan signifikan sebesar 0,128. Nilai signifikansi lebih besar dari $0,05(0,128>0,05)$ sehingga tidak ada dampak pengumuman merger dan akuisisi yang menghasilkan abnormal return signifikan pada periode $\mathrm{H}-2$. Di sisi lain, hasil pengujian data pada $\mathrm{H}-1$, diperoleh nilai t sebesar 0,048 dengan signifikan sebesar 0,962. Nilai signifikansi lebih besar 
dari $0,05(0,962>0,05)$ sehingga tidak ada dampak pengumuman merger dan akuisisi yang menghasilkan abnormal return signifikan pada periode $\mathrm{H}-1$.

Selanjutnya, untuk hasil pengujian data pada $\mathrm{H}_{0}$, diperoleh nilai $\mathrm{t}$ sebesar 0,225 dengan signifikan sebesar 0,803. Nilai signifikansi lebih besar dari 0,05 $(0,803>0,05)$ sehingga tidak ada dampak pengumuman merger dan akuisisi yang menghasilkan abnormal return signifikan pada periode H0. Kemudian, untuk hasil pengujian data pada $\mathrm{H}+1$, diperoleh nilai t sebesar $-0,468$ dengan signifikan sebesar 0,648. Nilai signifikansi lebih besar dari 0,05 (0,648>0,05) sehingga tidak ada dampak pengumuman merger dan akuisisi yang menghasilkan abnormal return signifikan pada periode $\mathrm{H}+1$. Sementara itu, untuk hasil pengujian data pada $\mathrm{H}+2$, diperoleh nilai t sebesar -0,263 dengan signifikan sebesar 0,797. Nilai signifikansi lebih besar dari 0,05 $(0,797>0,05)$ sehingga tidak ada dampak pengumuman merger dan akuisisi yang menghasilkan abnormal return signifikan pada periode $\mathrm{H}+2$. Dan untuk hasil pengujian data pada $\mathrm{H}+3$, diperoleh nilai $\mathrm{t}$ sebesar -0,178 dengan signifikan sebesar 0,261. Nilai signifikansi lebih besar dari $0,05(0,261>0,05)$ sehingga tidak ada dampak pengumuman merger dan akuisisi yang menghasilkan abnormal return signifikan pada periode $\mathrm{H}+3$.

Di sisi lain, untuk hasil pengujian data pada $\mathrm{H}+4$, diperoleh nilai t sebesar 0,876 dengan signifikan sebesar 0,398. Nilai signifikan lebih besar dari 0,05 $(0,398>0,05)$ sehingga tidak ada dampak pengumuman merger dan akuisisi yang menghasilkan abnormal return signifikan pada periode $\mathrm{H}+4$. Terakhir, untuk hasil pengujian data pada $\mathrm{H}+5$, diperoleh nilai t sebesar $-0,763$ dengan signifikan sebesar 0,46 . Nilai signifikan lebih besar dari $0,05(0,46>0,05)$ sehingga tidak ada dampak pengumuman merger dan akuisisi yang menghasilkan abnormal return signifikan pada periode $\mathrm{H}+5$.

\section{Pembahasan}

Berdasarkan hasil analisis data mengindikasikan bahwa selama 11 hari periode pengamatan tidak terdapat abnormal return yang signifikan pada seputaran waktu pengumuman merger dan akuisisi perusahaan. Hasil pengujian yang tidak signifikan ini membuktikan bahwa pasar tidak bereaksi selama periode pengamatan sebelum dan sesudah merger dan akuisisi. Respon yang tidak signifikan pada hari 
pengumuman ini menunjukkan pada hari pengumuman tersebut investor atau pasar sudah tidak memberikan reaksi yang berlebihan terhadap saham perusahaan yang melakukan merger dan akuisisi, hal ini informasi tentang merger dan akuisisi tersebut sudah mengejutkan dari jauh hari sebelum pengumuman.

Hasil penelitian ini sesuai dengan hasil penelitian sebelumnya yang dilakukan oleh Rusnanda dan Pardi (2013), yang juga menemukan hasil bahwa pasar tidak bereaksi terhadap pengumuman merger dan akuisisi. Ada beberapa kemungkinan mengapa peristiwa tersebut tidak mendapatkan respon dari para pelaku pasar modal, antara lain: pertama, pasar modal sudah bereaksi sebelum atau akan bereaksi setelah tanggal pengumuman (di luar periode penelitian). Kedua, para pelaku pasar modal khususnya investor sudah terbiasa menanggapi berbagai peristiwa merger dan akuisisi, sehingga peristiwa tersebut tidak menyebabkan para pelaku pasar modal merespon. Ketiga, para pelaku pasar modal belum dapat mempercayai sepenuhnya terhadap setiap informasi yang muncul baik informasi mengenai peristiwa ekonomi maupun non ekonomi, sehingga membuat pelaku pasar lebih berhati-hati terhadap setiap informasi yang ada.

Sementara itu, menurut penelitian dari Wibowo dan Pakereng (2001), nilai abnormal return yang negatif dikarenakan ketidak konsistenan efisiensi pasar dan adanya sugesti yang membuat perubahan harga pasar yang lebih tinggi. Mereka juga mengemukakan bahwa return yang negatif sebelum dan sesudah merger dan akuisisi adalah fakta yang tidak dapat dipungkiri sedangkan nilai abnormal return yang positif dalam periode sebelum dan sesudah merger dan akuisisi mengindikasikan bahwa investor mempunyai respon positif atas tindakan manajemen melakukan proses merger dan akuisisi perusahaan. Dalam pandangan investor, tindakan merger dan akuisisi tersebut dapat memperbaiki kondisi perusahaan baik dalam kaitannya dengan modal yang lebih besar dan harapan kinerja perusahaan yang lebih baik pada waktu yang akan datang. Selain itu, pasar menilai keputusan merger dan akuisisi yang dilakukan perusahaan merupakan yang tepat. Adanya optimisme investor mengenai kinerja proses merger dan akuisisi perusahaan menyebabkan naiknya permintaan akan saham-saham perusahaan yang melakukan merger dan akuisisi. Dengan demikian, penelitian ini menunjukkan hasil pengujian yang tidak signifikan, oleh karena itu dapat disimpulkan tidak terdapat dampak 
pengumuman merger dan akuisisi yang menghasilkan abnormal return signifikan pada periode disekitar tanggal pengumuman.

Selanjutnya, hasil penelitian ini berbeda dengan hasil penelitian Rumondang (2010) yang mampu membuktikan bahwa pengumuman merger dan akuisisi menghasilkan abnormal return positif yang signifikan pada periode di sekitar tanggal pengumuman. Atas dasar hasil tersebut, bahwa pasar telah mulai bereaksi pada periode sebelum tanggal pengumuman. Hasil ini mengindikasikan bahwa informasi mengenai peristiwa merger dan akuisisi ini telah bocor terlebih dahulu ke pelaku pasar modal. Nilai abnormal return yang positif dalam periode sebelum pengumuman mengindikasikan bahwa investor mempunyai respon positif atas tindakan manajemen melakukan proses merger dan akuisisi perusahaan. Selain itu, kebocoran informasi adanya perusahaan yang melakukan merger dan akuisisi menyebabkan adanya insider trading yang juga berkepentingan terhadap harga saham yang dimilikinya menyebabkan adanya aksi profit taking yang dilakukan sebelum tanggal pengumuman merger dan akuisisi, sehingga menyebabkan abnormal return yang signifikan.

\section{Kesimpulan, Implikasi, Saran dan Keterbatasan}

Dari pengujian yang telah dilakukan, penelitian ini menyimpulkan bahwa peristiwa merger dan akuisisi yang diumumkan oleh perusahaan mengakibatkan adanya abnormal return saham. Penelitian ini dilakukan dengan menggunakan periode pengamatan 11 hari dan terdapat abnormal return negatif dan positif yang tidak signifikan pada seputaran waktu pengumuman merger dan akuisisi perusahaan. Hasil pengujian yang tidak signifikan ini membuktikan bahwa pasar tidak bereaksi selama periode pengamatan baik sebelum dan sesudah merger dan akuisisi pada periode tahun 2016-2019. Selain itu, penelitian ini menghasilkan nilai abnormal return yang negatif selama 7 hari dikarenakan ketidakkonsistenan efisiensi pasar dan adanya sugesti yang membuat perubahan harga pasar yang lebih tinggi serta mengemukakan return yang negatif baik sebelum dan sesudah merger dan akuisisi. Hal ini berarti return saham yang diperoleh lebih kecil dari return pasar sedangkan nilai abnormal return yang positif dalam periode baik sebelum dan sesudah merger dan akuisisi dalam periode pengamatan selama 4 hari mengindikasikan bahwa investor mempunyai respon positif atas tindakan manajemen dalam melakukan 
proses merger dan akuisisi perusahaan. Hal ini berarti pemegang saham perusahaan memperoleh return saham diatas return pasar pada hari perdagangan tersebut.

Sementara itu, saran untuk penelitian selanjutnya adalah memperpanjang periode penelitian dengan harapan dapat diperoleh jumlah sampel dan observasi yang lebih banyak. Selain itu, peneliti selanjutnya juga bisa menggunakan metode yang berbeda dari penelitian ini yaitu mengukur abnormal return. Di sisi lain, penelitian ini juga memiliki beberapa keterbatasan yaitu jumlah sampel yang diperoleh saat periode pengamatan yaitu 12 perusahaan yang melakukan merger dan akuisisi. Di sisi lain, penelitian ini menggunakan pendekatan atau model penentuan abnormal return yang mengasumsikan bahwa actual return konstan sehingga kemungkinannya dapat berpengaruh pada hasil penelitian yang tidak terdapat dampak abnormal return pada periode sebelum dan setelah pengumuman merger dan akuisisi perusahaan.

Keterbatasan penelitian ini adalah jumlah sampel yang sedikit yaitu 12 perusahaan di Bursa Efek Indonesia yang melakukan merger dan akuisisi pada periode 2016-2019 dan terdapat harga sahamnya.

\section{Referensi}

Brigham \& Houston. 2014. Dasar-Dasar Manajemen Keuangan. Jakarta: Salemba Empat

Haryani, Iswi. (2011) Merger, Konsolidasi, Akuisisi, dan Pemisahan Perusahaan: Cara Cerdas Mengembangkan dan Memajukan Perusahaan. Jakarta: Visi Media

Hartono, Jogiyanto. (2017). Teori Portofolio dan Analisis Investasi. Edisi kesebelas. Yogyakarta: BPFE

Mardiyanto, Handono. (2009). Inti Sari Manajemen Keuangan : Teori, Soal dan Jawaban. Jakarta: Grasindo

Moin, Abdul. (2010). Merger, akuisisi dan divestasi. Edisi 2. Yogyakarta: Ekonisia

Nugroho, Muhammad Aji. (2010). Analisis Perbandingan Kinerja Keuangan Perusahaan Sebelum dan Sesudah Merger dan Akuisisi (Pada Perusahaan Pengakuisisi, Periode 2002-2003). Skripsi Fakultas Ekonomi. Universitas Diponegoro. Semarang

Pratama, Yuda. (2017). Analisis reaksi pasar sebelum dan sesudah peristiwa merger dan akuisisi. Skripsi Fakultas Ekonomi dan Bisnis, Universitas Lampung

Rumondang, Astri. (2010). Analisis Dampak Pengumuman Merger Dan Akuisisi Terhadap Abnormal Return Saham Perusahaan Studi Pada Bursa Efek Indonesia Periode Tahun 2000-2006). Skripsi Fakultas Ekonomi, Universitas Sebelas Maret. Surakarta

Rusnanda, Eliya Wahyu dan Pardi. (2013). Analisa pengaruh pengumuman merger dan akuisisi terhadap abnormal return saham bank umum di Bursa Efek Indonesia. Graduasi, 29, 89-101. 
Setiawan, I Putu Doni dan Ni Ketut Rasmini. (2018). Analisis Perbandingan Kinerja Keuangan Perusahaan Sebelum dan Sesudah Merger dan Akuisisi Periode 2011-2014. E-Jurnal Akuntansi, 24(1), 687-714. doi:10.24843/EJA.2018.v24.i01.p26

Sihombing, N. dan M. Kamal. (2016). Analisis Pengaruh Pengumuman Merger dan Akuisisi Terhadap Abnormal Return Saham dan Kinerja Keuangan Perusahaan (Studi pada perusahaan yang melakukan Merger dan Akuisisi pada Tahun 2011 dan terdaftar di Bursa Efek Indonesia). Diponegoro Journal of Management, 5(3), 1077-1091. Retrieved from https://ejournal3.undip.ac.id/index.php/djom/article/view/14882

Sugiyono. (2017). Metode Penelitian Kuantitatif, Kualitatif, dan R\&D. Bandung: Alfabeta

Tandelilin, Eduardus. (2010). Portofolio dan Investasi Teori dan Aplikasi. Edisi pertama. Yogyakarta: Kanisius

Tarigan, Josua. (2016). Merger dan Akuisisi: Dari Perspektif Strategis dan Kondisi Indonesia. Yogyakarta: Ekuilibria.

Wibowo dan Pakereng. 2001. Pengaruh Pengumuman Merger Dan Akuisisi terhadap Return Saham Perusahaan Akuisitor Dan Non Akuisitor Dalam Sektor Industri Yang Sama Di Bursa Efek Jakarta. Jurnal Ekonomi dan Bisnis Indonesia. Vol. 16. No. 4: 372-387. 